\title{
Egg Parasitoids of Cabbage Caterpillars in Sri Lanka: A Search for Biocontrol Agents
}

\author{
S.A.A. Singhamuni ${ }^{1}$, K.S. Hemachandra ${ }^{2 *}$ and P.G.A.S. Warnasooriya ${ }^{2}$
}

Date Received: $1^{\text {st }}$ June 2020 / Date Accepted: $13^{\text {th }}$ October 2020

\begin{abstract}
Purpose : Management of cabbage caterpillar complex through augmentative release of egg parasitoids has been suggested considering the current issues in insecticide application, mainly the effect on human health, non-target effects and environmental pollution. Use of local egg parasitoid species is preferred considering the environmental risk associated with the use of exotic species; therefore, this study was conducted to examine the egg parasitoid guild of cabbage caterpillars in Sri Lanka.

Research Method: Field survey was conducted during January 2012 to May 2013 in major cabbage growing areas in the mid-country. Eggs of cabbage caterpillars were collected and reared them until the emergence of host larvae or adult parasitoids. Emerged parasitoids were preserved in $70 \%$ ethanol, and prepared the microscopic slides upon the dissection of male genitalia. Parasitoids were identified by using taxonomic keys and Trichogramma literature as per the protocol suggested by Natural History museum, London and the identities were confirmed by the taxonomist in Natural history museum in London.
\end{abstract}

Findings : Trichoplusia ni, Spodoptera litura, Crocidolomia pavonana and Plutella xylostella were found as the members of cabbage caterpillar complex. Two egg parasitoid species: Trichogramma chilonis Ishi and Trichogramma achaeae Nagaraja and Nagarkatti were found attacking eggs of cabbage caterpillars. Trichogramma chilonis has been reported previously in Sri Lanka but Trichogramma achaeae is the first country report. T. chilonis was widely distributed and caused for higher level of parasitism than T. achaeae. The highest level of parasitism (67\%) by both species was found in Trichoplusia ni eggs which was significantly different from other species. Level of parasitism of caterpillar eggs was significantly varied between pesticide free fields (16.8\%) and conventional fields (13.1\%).

Research Limitation : The study of behavioral characters of these parasitoids is required to assess the suitability as biocontrol agents; as an initial step for augmentative biocontrol, the locally available egg parasitoids were reported in this study.

Originality/Value : These findings would be contributing Sri Lankan agriculture sector to develop the augmentative biocontrol approach to manage the cabbage caterpillar complex and to produce pesticide residues free crop produce.

Keywords: Crocidolomia pavonana, Parasitism, Plutella xylostella, Spodoptera litura, Trichogramma spp., Trichoplusia $n i$

\section{INTRODUCTION}

Brassicas, including cabbage, radish, knolkohl (kohlrabi), and cauliflower are major vegetable crops in Sri Lanka. Of these, cabbage, which is most widely cultivated, is grown on over 4000 ha. Insect attack on cabbage is a major production constraint. Serious damage is caused by the cabbage caterpillar complex,

1 Postgraduate Institute of Agriculture, University of Peradeniya, Peradeniya, Sri Lanka

2* Department of Agricultural Biology, Faculty of Agriculture, University of Peradeniya, Peradeniya, Sri Lanka

ks_hemachandra@agri.pdn.ac.lk

(D) http://orcid.org/0000-0002-1968-5105 
which includes the larvae of diamondback moth (Plutella xylostella Linnaeus (Lepidoptera: Plutellidae)), cabbage semi-looper (Trichoplusia ni Hübner (Lepidoptera: Noctuidae)), cabbage cluster caterpillar (Crocidolomia pavonana Fabricius (Lepidoptera: Crambidae)), and cabbage webworm (Hellula undalis Fabricius (Lepidoptera: Crambidae)) (Ketipearachchi et al., 1992). Aphids (Brevicoryne brassicae (Linnaeus) (Hemiptera: Aphididae)), shield bugs (Bagrada hilaris (Burmeister) (Hemiptera: Pentatomidae)) and cutworms (Agrotis spp. (Lepidoptera: Noctuidae)) also cause damage.

Managing of the cabbage caterpillar complex is a challenge for brassica growers and currently foliar insecticide applications are commonly used. Department of Agriculture has recommended 13 insecticides for the control of cabbage caterpillar complex e.g; Chlorfluazuron 50g/1 EC, Etofenprox 100g/1 EC and Emamectin benzoate 5\% SG (Department of Agriculture, 2015). Development of insecticide resistance, secondary pest outbreaks and pest resurgence are likely problems arising from excessive insecticide use (Van den Bosch et al., 1982). Environment pollution and pesticide residues on crop harvest lead to human health problems; hence, minimizing of insecticide application on crucifer crops has been proposed.

Biological control is an important component of IPM and it is considered as safe, environmentally friendly, economical, and sustainable approach (DeBach, 1964). The three main approaches to biological control of arthropods are classical, augmentative release and conservation control (Bale et al., 2008). Of the three, augmentation and release of indigenous parasitoids appears to be the most applicable approach for management of the cabbage caterpillar complex in Sri Lanka, as it poses less risk to non-target organisms and is logistically simpler. Some researchers have examined the parasitoid fauna in vegetable pests within the country (De Silva, 1961; Ketipearachchi, 2002; Nagalingam et al., 2007). Locally available parasitoids of cabbagefeeding Lepidoptera have been documented (Jasudasan and Yogaratnam, 1984). However, a major limitation of using larval and pupal parasitoids in cabbage caterpillar control is that plant damage occurs before parasitoid-induced mortality occurs. Thus, using egg parasitoids to kill members of the cabbage caterpillar complex at the egg stage is a desirable objective.

Egg parasitoids (Trichogramma spp.) have been successfully used in more than 56 countries and over 32 million ha are being treated with Trichogramma spp. to manage lepidopteran insects (Hassan, 1993). Trichogramma spp. have a worldwide distribution and about 145 species have been described in 80 genera (Pinto and Stouthamer, 1994). Augmentation and release of Trichogramma spp. has been successful in many other crops such as cotton, sugar beet, tomato, apple etc; therefore, cabbage insect control using egg parasitoids is suggested (Consoli et al., 2010).

The objective of this study was to identify local egg parasitoids of cabbage caterpillars in Sri Lanka, as a first step towards their use in a biological control programme through augmentative release. Local parasitoid species are expected to be well adapted to the local climate and habitat (Hassan, 1989). Once candidate egg parasitoids are identified, the most suitable species for augmentative releases can be selected on the basis of the ease of mass rearing, their efficacy against target hosts, and their survival under local cultivation systems. In Sri Lanka, parasitoid augmentation has not been widely implemented but there is potential for farmers to operate their own programmes of mass rearing and release.

\section{MATERIALS AND METHODS}

This study was conducted from January 2012 to May 2013, and was based in the Department of Agricultural Biology, University of Peradeniya, Sri Lanka. The study has three major components: (a) Sampling of lepidopteran eggs in the cabbage ecosystem (b) Laboratory rearing of the collected eggs (c) Preparation of slides of adult parasitoids and identification of species.

\section{Sampling of eggs in the cabbage ecosystem}

Field surveys were conducted in selected cabbage 
fields in vegetable growing areas at six locations (Thalathuoya, Galgediyawa, Alawathugoda, Hindagala, Ihalawela and Dodangolla) within the mid country (300 - $900 \mathrm{~m}$ mean sea level) of Sri Lanka. Selection of fields for sampling was based on the level of insect infestation, accessibility for regular sampling, cooperation of farmers and pattern of insecticide use. Cabbage fields were selected in two cultivation systems: conventionally managed fields receiving foliar insecticides, and pesticide-free fields that received no insecticide applications.

Selected fields were examined at weekly intervals, and collections were made of the eggs of brassica-feeding Lepidoptera. In addition, eggs of beneficial arthropods; coccinellids and spiders, were collected to assess the non-target effects of egg parasitoids. Egg collections were made by examining the cabbage plants, using a hand lens as required. When eggs were found they, and a surrounding disc of leaf were removed from the plant using a cork borer (20mm diameter). Each of the leaf discs with attached eggs was placed separately in a clear plastic vial $(2.5 \mathrm{~cm}$ diameter, $5.5 \mathrm{~cm}$ height), labeled with a code which referenced the field collection data. Eggs from each cabbage plants were placed in separate vials with further separation by caterpillar species. Identity of the caterpillar species was based on morphological characteristics of eggs or egg masses. The collected eggs were temporally stored in a cooler pack and transported to the laboratory.

\section{Laboratory rearing of collected eggs}

In the laboratory, eggs were identified using morphological characteristic examined at magnification $\times 50$ under a dissecting microscope (Meiji, Japan). Host eggs or egg masses when eggs could not be separated, were individually placed in clear plastic vials $(2.5 \mathrm{~cm}$ diameter, $5.5 \mathrm{~cm}$ height). Vials were maintained at room temperature and examined everyday for the emergence of parasitoid adults or host larvae. Emerged parasitoid adults were separated and preserved in $70 \%$ ethanol for identification, attaching all collection data. In addition, the number and identity of adults emerged from each host was recorded in cases where superparasitism or multiparasitism was observed.

Table 01: Details of cabbage fields where host eggs were collected for assessment of egg parasitoid communities.

\begin{tabular}{|c|c|c|c|c|}
\hline $\begin{array}{l}\text { Pest control } \\
\text { regime }\end{array}$ & Site name & $\begin{array}{l}\text { Longitude and } \\
\text { latitude }\end{array}$ & Sampling period & Site information \\
\hline \multirow{4}{*}{ Conventional } & Thalathuoya & $\begin{array}{l}7^{0} 14 ' 30.95^{\prime \prime} \mathrm{N} \\
80^{\circ} 40^{\prime} 32.15^{\prime \prime} \mathrm{E}\end{array}$ & $\begin{array}{l}\text { January, 2012-May, } \\
2013\end{array}$ & $\begin{array}{l}\text { Conventional vegetable } \\
\text { cultivation, surrounded by } \\
\text { perennial trees, }\end{array}$ \\
\hline & Galgediyawa & $\begin{array}{l}7^{0} 10^{\prime} 48.31^{\prime \prime} \mathrm{N} \\
80^{\circ} 35^{\prime} 8.20^{\prime \prime} \mathrm{E}\end{array}$ & January-June, 2012 & $\begin{array}{l}\text { Conventional vegetable } \\
\text { cultivation, bordering to } \\
\text { vegetable cultivations }\end{array}$ \\
\hline & Alawathugoda & $\begin{array}{l}7^{0} 26^{\prime} 11.51 \text { '” } \\
80^{\circ} 34^{\prime} 22.34^{\prime \prime} \mathrm{E}\end{array}$ & May-November, 2012 & $\begin{array}{l}\text { Conventional vegetable } \\
\text { cultivation, Surrounding } \\
\text { environment consisted with } \\
\text { fallow field. }\end{array}$ \\
\hline & Hindagala & $\begin{array}{l}7^{0} 14 ' 2.11 \text { 'N } \\
80^{0} 36^{\prime} 4.72 ” \mathrm{E}\end{array}$ & April-August, 2012 & $\begin{array}{l}\text { Conventional vegetable land, } \\
\text { surrounding with paddy }\end{array}$ \\
\hline \multirow{3}{*}{ Pesticide-free } & Ihalawela & $\begin{array}{c}7^{0} 10^{\prime} 7.18^{\prime \prime} \mathrm{N} \\
80^{\circ} 34^{\prime} 39.37^{\prime \prime} \mathrm{E}\end{array}$ & February-May, 2012 & $\begin{array}{l}\text { Pesticide free vegetable } \\
\text { cultivation surrounded by } \\
\text { paddy land and manioc. }\end{array}$ \\
\hline & & & & Pesticide free vegetable \\
\hline & Dodangolla & $\begin{array}{l}7^{0} 17^{\prime} 25.13^{\prime \prime} \mathrm{N} \\
80^{\circ} 42^{\prime} 11.48^{\prime \prime} \mathrm{E}\end{array}$ & May-July, 2012 & $\begin{array}{c}\text { cultivation surrounded by } \\
\text { teak hedge row and cultivated } \\
\text { vegetable land. }\end{array}$ \\
\hline
\end{tabular}




\section{Preparation and identification of adult parasitoids}

Adult egg parasitoids were identified according to the protocol described by Noyes (2016). The male adult parasitoids were separated under the microscope on the basis of antennal characteristics, and carefully card mounted and preserved as dry specimens. Using the external morphology, different species were identified and series were prepared.

Card mounted specimens were mounted on microscope slides using the procedure of Platner et al., 1999. The wings were separated and mounted in Canada balsam on a glass slide. The remainder of the insect was boiled in $10 \%$ potassium hydroxide solution for 5 minutes, and then raised through an ethanol dehydration series to absolute ethanol before transferring to clove oil. The dehydrated specimen was dissected in thin balsam on a glass slide under the dissecting microscope. The antennae, head capsule, wings, body and the genitalia were separately mounted in balsam under $8 \mathrm{~mm}$ diameter coverslips. Prepared slides were kept at $35^{\circ} \mathrm{C}$ in an oven for 10 days until the slides were completely dry.

Slides were examined under a compound light microscope $(\mathrm{x} 400)$ and the structure of the genitalia was compared with the illustrations in Trichogramma identification keys and the original descriptions. Species identities were confirmed on morphological characteristics by sending representative specimens to the Natural History Museum, London, U.K.; this was followed by verification using molecular techniques at University of California, U.S.A.

\section{Data analysis}

Percent parasitism was estimated as the number of parasitoid adults divided by the total number of host eggs multiplied by 100 (Van Driesche, 1983). The data were analyzed by using Chi square tests in SYSTAT 11, with an alpha level for significance of 0.05 .

\section{RESULTS AND DISCUSSION}

Eggs of four cabbage feeding caterpillar species: T. ni, S. litura, C. pavonana and P. xylostella were found in the sampled cabbage fields (Table 02). Trichoplusia ni and C. pavonana were found in all fields. T. $n i$ and C. pavonana were more abundant. Plutella xylostella appears to be uncommon though it has been reported as a common cabbage pest in Sri Lanka. The relative abundance of species of the cabbage caterpillar complex may vary with geographical location, time of the year and seasonal variation in host plant availability in an area. Hellula undalis, a member of the cabbage caterpillar complex, was not found during this study. The lepidopteran eggs collected in this study had been parasitized by two egg parasitoid species: Trichogramma chilonis Ishi (Hymenoptera: Trichogrammatidae) and Trichogramma achaeae Nagaraja and Nagarkatti (Hymenoptera: Trichogrammatidae). Trichogramma chilonis was observed parasitizing Homona coffearia (Nietner) (Lepidoptera: Tortricidae) eggs in Sri Lankan tea plantations in 1969 (Nagarkatti and Nagaraja, 1971) but, until our study, there had been no formally published reports of the species in the country since. Trichogramma achaeae has never been reported in Sri Lanka; hence, this is the first country report. Egg parasitoids have not been well studied in Sri Lanka. Only 10 species belonging to the Family Trichogrammatidae have been recorded (Noyes, 2016).

During this study, a total of 19,920 host eggs of cabbage caterpillar were collected. Of these eggs, 2,877 eggs had been parasitized, an overall level of parasitism of $14.44 \%$. The level of parasitism of all host eggs by all parasitoid species varied significantly among the six sampling sites $(\chi 2=$ $627.8, \mathrm{df}=5, \mathrm{P}<0.001)$ and the total parasitism of host eggs by all species of parasitoids was in conventional fields was lower than in pesticidefree fields $(\chi 2=57.0, \mathrm{df}=1, \mathrm{P}<0.001)$. 
Table 02: Collected eggs of cabbage caterpillars and egg parasitoids that emerged from them.

\begin{tabular}{|c|c|c|c|c|c|c|c|}
\hline $\begin{array}{l}\text { Pest control } \\
\text { regime }\end{array}$ & $\begin{array}{l}\text { Site name } \\
\text { (number of } \\
\text { samples) }\end{array}$ & Host species & $\begin{array}{l}\text { Number of } \\
\text { collected host } \\
\text { eggs }\end{array}$ & $\begin{array}{c}\text { Number of } \\
\text { parasitized } \\
\text { eggs }\end{array}$ & $\begin{array}{c}\text { Total } \\
\text { parasitism (\%) }\end{array}$ & $\begin{array}{l}\text { Parasitism } \% \\
\text { by } T \text {. chilonis }\end{array}$ & $\begin{array}{l}\text { Parasitism \% } \\
\text { by T. achaeae }\end{array}$ \\
\hline \multirow{20}{*}{ Conventional } & \multirow{4}{*}{$\begin{array}{l}\text { Thalathuoya } \\
\text { (16) }\end{array}$} & Trichoplusia ni & 3029 & 1506 & 49.71 & 37.24 & 28.32 \\
\hline & & Plutella xylostella & 34 & 11 & 32.35 & 32.35 & 0 \\
\hline & & Spodoptera litura & 3000 & 46 & 1.53 & 1.53 & 0 \\
\hline & & Crocidolomia pavonana & 2400 & 10 & 0.41 & 0.41 & 0 \\
\hline & \multicolumn{2}{|c|}{ Site totals and parasitism } & 8463 & 1573 & 18.59 & 12.1 & 8.0 \\
\hline & \multirow{4}{*}{$\begin{array}{c}\text { Galgediyawa } \\
\text { (7) }\end{array}$} & Trichoplusia ni & 125 & 54 & 43.2 & 43.2 & 0 \\
\hline & & Plutella xylostella & 60 & 5 & 8.33 & 8.33 & 0 \\
\hline & & Spodoptera litura & 1250 & 0 & 0 & 0 & 0 \\
\hline & & Crocidolomia pavonana & 1050 & 0 & 0 & 0 & 0 \\
\hline & \multicolumn{2}{|c|}{ Site totals and parasitism } & 2485 & 59 & 2.37 & 2.3 & 0 \\
\hline & \multirow{4}{*}{$\begin{array}{c}\text { Alawathugoda } \\
\text { (5) }\end{array}$} & Trichoplusia ni & 346 & 121 & 34.97 & 34.97 & 0 \\
\hline & & Plutella xylostella & 0 & 0 & 0 & 0 & 0 \\
\hline & & Spodoptera litura & 750 & 0 & 0 & 0 & 0 \\
\hline & & Crocidolomia pavonana & 750 & 0 & 0 & 0 & 0 \\
\hline & \multicolumn{2}{|c|}{ Site totals and parasitism } & 1846 & 121 & 6.55 & 6.5 & 0 \\
\hline & \multirow{4}{*}{ Hindagala (4) } & Trichoplusia ni & 15 & 8 & 53.33 & 53.33 & 0 \\
\hline & & Plutella xylostella & 0 & 0 & 0 & 0 & 0 \\
\hline & & Spodoptera litura & 0 & 0 & 0 & 0 & 0 \\
\hline & & Crocidolomia pavonana & 600 & 0 & 0 & 0 & 0 \\
\hline & \multicolumn{2}{|c|}{ Site totals and parasitism } & 615 & 8 & 1.30 & 1.3 & 0 \\
\hline \multicolumn{3}{|c|}{ Totals and parasitism for conventional sites } & 13409 & 1761 & 13.13 & 8.9 & 4.91 \\
\hline \multirow{9}{*}{$\begin{array}{l}\text { Pesticide- } \\
\text { free }\end{array}$} & \multirow{4}{*}{ Ihalawella (11) } & Trichoplusia ni & 1301 & 876 & 67.33 & 67.33 & 0 \\
\hline & & Plutella xylostella & 77 & 21 & 27.2 & 27.2 & 0 \\
\hline & & Spodoptera litura & 2250 & 5 & 0.22 & 0.22 & 0 \\
\hline & & Crocidolomia pavonana & 1650 & 0 & 0 & 0 & 0 \\
\hline & \multicolumn{2}{|c|}{ Site totals and parasitism } & 5278 & 902 & 17.09 & 18.0 & 0 \\
\hline & \multirow{4}{*}{ Dodangolla (9) } & Trichoplusia ni & 326 & 214 & 65.64 & 59.27 & 31.28 \\
\hline & & Plutella xylostella & 7 & 0 & 0 & 0 & 0 \\
\hline & & Spodoptera litura & 194 & 0 & 0 & 0 & 0 \\
\hline & & Crocidolomia pavonana & 706 & 0 & 0 & 0 & 0 \\
\hline & \multicolumn{2}{|c|}{ Site totals and parasitism } & 1233 & 214 & 17.36 & 11.3 & 6.3 \\
\hline \multicolumn{3}{|c|}{ Totals and parasitism for pesticide-free sites } & 6511 & 1116 & 17.14 & 16.67 & 1.33 \\
\hline
\end{tabular}

Parasitism of host eggs by $T$. chilonis occurred in all sites, and the level of parasitism of all host species was $11.5 \%$. Parasitism of all host eggs by $T$. chilonis was significantly different among sampling sites $(\chi 2=527.41, \mathrm{df}=5, \mathrm{P}<0.001)$. Trichogramma chilonis parasitized the eggs of all recorded caterpillar species at Thalathuoya. In all sites, $T$. $n i$ was the species with the highest level of parasitism (Table 02). Parasitism of host eggs by $T$. chilonis was significantly influenced by pest control regime $(\chi 2=256.71, \mathrm{df}=1, \mathrm{P}<0.001)$ : in pesticide-free fields parasitism level was $16.67 \%$ and in conventional fields it was $8.9 \%$.

Trichogramma achaeae was found only at Dodangolla and Thalathuoya (Table 02); and was recorded only from T.ni eggs. Level of total parasitism of host eggs by T. achaeae in pesticide free fields was $1.33 \%$ and conventional fields $4.91 \%$ - a significant difference $(\chi 2=134.01$, $\mathrm{df}=1, \mathrm{P}<0.001)$.

Trichogramma chilonis, was present in all sampling sites regardless of farming and pest management practices; this may be an indication of its adaptability and potential to be effective in diverse farming systems. Further, T. chilonis attacked all species of cabbage caterpillars that were present in each location indicating the host range.

Total parasitism of $T$. $n i$ eggs was relatively high when both parasitoids: $T$. chilonis and $T$. achaeae attack eggs as happened at Thalathuoya and 
Dodangolla. This signifies the possibility of existence of both species in the same field and sharing of the resources. This is a good character in potential biocontrol agents.

Trichoplusia ni eggs had the highest level of parasitism among all host species found in sampling sites, and was parasitized by both Trichogramma species. Over all sites, the level of parasitism of $T$. $n i$ eggs by both parasitoids was $54 \%$. Level of parasitism of $T$. $n i$ in pesticide free field and conventional fields were 67.0 and $54.1 \%$ respectively which was significantly different. Other host species were parasitized only by $T$. chilonis. Parasitism of P. xylostella eggs, averaged over all sites, was $20.7 \%$, but was observed in only three sites. Parasitism by T. chilonis of S. litura eggs was observed in only two sites, and of $C$. pavonana eggs were seen only at Thalathuoya.

A total of 840 eggs of non-target organisms were collected from the cabbage fields sampled in this study. Of these, 62 were spider eggs, and the remainders were eggs of Coccinellidae. No Trichogramma parasitoids emerged from these eggs (Table 03).

The highest total parasitism was recorded in cabbage fields in Thalathuoya. Although the study site receives pesticides, it is surrounded by dense trees with rich undergrowth. The higher total parasitism percentage may be due to dispersal of parasitoids to the vegetable fields from these surrounding natural habitats. This finding provides evidence on importance of natural habitat for conservation of natural enemies. Cabbage fields at Ihalawella and Dodangolla had comparatively high parasitism levels, probably because these fields were managed without pesticides. Fields at Alawathugoda, Galgediyawa and Hindagala fields were managed with frequent applications of pesticides, and had lower levels of parasitism. High levels of parasitism in pesticide free fields have been recorded for Trichogramma pretiosum on Heliothis virescences (Bull and House, 1983; Suh et al., 2000; Vieira et al., 2001; Brunner et al., 2001; Takada et al., 2001).

Levels of parasitism of $C$. pavonana and $S$. litura were low. This is associated with the morphology of the egg mass. Unlike T. ni and P. xylostella which lay eggs singly or in small groups, C. pavonana and $S$. litura lay eggs in masses. Crocidolomia pavonana laid flat eggs which overlap and are arranged in a single layer. Parasitoids attempt to parasitize these egg masses but are unsuccessful due to the physical barrier. A few parasitized eggs did not produce adult parasitoids because early eclosing larvae destroy the eggs.

As no non-target parasitism was recorded, both $T$. chilonis and T. achaeae appear to be reasonably safe parasitoids to promote in the cabbage ecosystem to manage the cabbage caterpillar complex. The wider distribution and relatively high level of parasitism of $T$. chilonis make it a better prospect to use in augmentation biological control than $T$. achaeae, although augmentation releases of both species would appear to be beneficial, particularly where the main pest species in the cabbage caterpillar complex is $T$. ni.

Table 03: Numbers of non-target arthropod eggs collected and levels of parasitism.

\begin{tabular}{ccccc}
\hline $\begin{array}{c}\text { Pest control } \\
\text { regime }\end{array}$ & $\begin{array}{c}\text { Site name } \\
\text { and number of samples }\end{array}$ & Host taxon & $\begin{array}{c}\text { Number of host } \\
\text { eggs collected }\end{array}$ & $\begin{array}{c}\text { Number of emerged } \\
\text { parasitoids }\end{array}$ \\
\hline \multirow{4}{*}{ Conventional } & Thalathuoya (16) & Coccinellid species & 296 & 0 \\
& Galgediyawa (7) & Coccinellid species & 34 & 0 \\
& Alawathugoda (5) & Spider eggs & 6 & 0 \\
& Hindagala (4) & Coccinellid species & 21 & 0 \\
\hline \multirow{3}{*}{ Pesticide-free } & Ihalawela (11) & Coccinellid species & 321 & 0 \\
& Dodangolla (9) & Coccinellid species & 106 & 0 \\
& & & & 0 \\
\hline
\end{tabular}




\section{CONCLUSIONS}

Four major cabbage caterpillar species: Trichoplusia ni, Spodoptera litura, Crocidolomia pavonana and Plutella xylostella were present in the sampled cabbage fields. Trichoplusia $n i$ and $C$. pavonana were more abundant in cabbage crops in mid-country area. Two species of Trichogramma: T. chilonis and T. achaeae were present in cabbage cultivations parasitizing caterpillar eggs. Trichoplusia ni eggs were highly susceptible for the parasitism and C. pavonana and S. litura eggs were less liable to parasitism. Trichogramma chilonis was geographically widely distributed and parasitized comparatively higher number of host eggs than Trichogramma achaeae. Trichogramma chilonis most of the time tolerates conventional farming practices than T. achaeae. Non target effect of T. chilonis or T. achaeae was not detected; hence, there is a high potential to control cabbage caterpillars, particularly $T$. $n i$ by using locally available parasitoid species: T. chilonis and T. achaeae.

\section{ACKNOWLEDGEMENT}

Financial assistance for this research project was received through National Science Foundation, Sri Lanka (Rg/2011/Ag/05).

\section{Declaration of interest statement}

The authors declare no conflicts of interest.

\section{REFERENCES}

Bale, J.S., van Lenteren, J.C. and Bigler, F. (2008). Biological control and sustainable food production. Philosophical Transactions of the Royal Society Biological Sciences. 363(1492): 761-776. DOI: https://doi.org/10.1098/rstb.2007.2182

Brunner, J.F., Dunley, J.E., Doerr, M.D. and Beers, E.H. (2001). Effect of pesticides on Colpoclypeus florus (Hymenoptera: Eulophidae) and Trichogramma platneri (Hymenoptera: Trichogrammatidae), parasitoids of leaf rollers in Washington. Journal of Economic Entomology. 94(5): 1075-1084. DOI: 10.1603/0022-0493-94.5.1075

Bull, D.L. and House, V.S. (1983). Effects of different insecticides on parasitism of host eggs by Trichogramma pretiosum Riley. Southwestern Entomologist. 8, 46-53.

Consoli, F.L., Parra, J.R.P and Zucchi, R.A. (2010). Egg parasitoids in agroecosystems with emphasis on Trichogramma. Springer Science \& Business Media. Netherlands. 473pp. DOI: https://doi. org/10.1007/978-1-4020-9110-0

De Silva, M.D. (1961). A preliminary list of the native parasites and predators of insect pests in Ceylon. Tropical Agricultural Research. (CXVII), 115-141.

DeBach, P. (1964). Successes, trends and future possibilities. In: Biological Control of Insect Pests and Weeds. (DeBach, P. Ed.). Reinhold, New York, USA. 673-713.

Department of Agriculture (2015). Pest management recommendations. Department of Agriculture, Peradeniya, Sri Lanka. Retrieved from https:/www.doa.gov.lk /SCPPC/images/ROP/ Introduction_to_book.pdf. 21.05.2020.

Hassan, S.A. (1989). Selection of suitable Trichogramma strains to control the codling moth, Cydia pomonella and the two summer fruit tortrix moths Adoxophyes arana, Pendemis heparana (Lepidoptera: Tortricidae). Entomophaga. 34(1): 19-27. DOI: https://doi.org/10.1007/ BF02372583

Hassan, S.A. (1993). The mass rearing and utilization of Trichogramma to control lepidopteran pests: Achievement and outlook. Pesticide Science. 37(4): 387-391. DOI: https://doi.org/10.1002/ ps. 2780370412 
Jasudasan, D. and Yogaratnam, V. (1984). Seasonal population fluctuations of the diamondback moth, Plutella xylostella (L.) and its larval parasitoids in the uplands of Sri Lanka. Journal of Tropical Agriculturist. 140: 27-40.

Ketipearachchi, Y. (2002). Hymenopteran parasitoids and hyperparasitoids of crop pests at Aralaganwila in the North Central province in Sri Lanka. Annals of the Sri Lanka Department of Agriculture (ASDA). 4: 293-306.

Ketipearachchi, Y., Ahangama, D. and Wijayagunasekara, H.N.P. (1992). Population Distribution and Identification of Lepidopteran Pests on Cabbage, Brassica oleracea Capitata L. in the Mid Country of Sri Lanka. Tropical Agricultural Research. 4: 168-179.

Nagalingam, T., Wijayagunasekara, H.N.P., Hemachandra, K.S. and Nugaliyadde, L. (2007). Parasitoids of Liriomyza sativae Blanchard (Diptera: Agromyzidae) in the mid country of Sri Lanka. Tropical Agricultural Research. 19: 59-68. Retrieved from http://192.248.43.136/ handle/1/1993

Nagarkatti, S. and Nagaraja, H. (1971). Redescriptions of some known species of Trichogramma (Hym., Trichogrammatidae), showing the importance of the male genitalia as a diagnostic character. Bulletin of Entomological Research. 61(1): 13-31. DOI: https://doi.org/10.1017/ S0007485300057412.

Noyes, J.S. (2016). Universal Chalcidoidea Database. Retrieved from http:/www.nhm.ac.uk/ chalcidoids. 15.07.2016.

Pinto, J.D. and Stouthamer, R. (1994). Systematics of the Trichogrammatidae with emphasis on Trichogramma. In: Biological control with egg parasitoids. (Wajnburg, E.E. and Hassan, S.A. Eds.). CAB International, London, UK. 1-36.

Platner, G.R., Velten, R.K., Planoutene, M. and Pinto, J.D. (1999). Slide-mounting techniques for Trichogramma (Trichogrammatidae) and other minute parasitic Hymenoptera. Entomological News. 110(1): 56-64.

Suh, C.P.C., Orr, D.B. and Van Duyn, J.W. (2000). Effect of insecticides on Trichogramma exiguum (Trichogrammatidae: Hymenoptera) preimaginal development and adult survival. Journal of Economic Entomology. 93(3): 577-583. DOI: 10.1603/0022-0493-93.3.577

Takada, Y., Kawamura, S. and Tanaka, T. (2001). Effects of various insecticides on the development of the egg parasitoid Trichogramma dendrolimi (Hymenoptera: Trichogrammatidae). Journal of Economic Entomology. 94(6):1340-1343. DOI: https://doi.org/10.1603/0022-0493-94.6.1340

Van den Bosch, R., Messenger, P.S., and Gutierrez, A.P. (1982). An introduction to biological Control. NY: Plenum Press, New York, USA. 247pp. DOI 10.1007/978-1-4757-9162-4

Van Driesche, R.G. (1983). Meaning of 'percent parasitism' in studies of insect parasitoids. Environmental Entomology. 12(6): 1611-1622. DOI: https://doi.org/10.1093/ee/12.6.1611

Vieira, A., Oliveira, L. and Garcia, P. (2001). Effects of conventional pesticides on the preimaginal developmental stages and on adults of Trichogramma cordubensis (Hymenoptera: Trichogrammatidae), Biocontrol Science and Technology. 11(4): 527-534. DOI: 10.1080/0958315012006755 